\title{
Association between attitudes towards Internet usage and health practices in high-school students in 2 schools in Turkey: a cross-sectional study
}

N. Kaya ${ }^{1}$, T. Aști ${ }^{2}$, I. Kaya ${ }^{3}$, S. Yaylaci ${ }^{4}$, H. Kaya ${ }^{5}$, N. Turan ${ }^{5}$ and G. Özdemir Aydin ${ }^{5}$

$$
\begin{aligned}
& \text { الترابطبين الاتجاهات تجاه استخدام الإنترنت والمارسات الصحية لدى طالاب المرحلة الثانوية في مدرستين في تركيا: دراسة مقطعية }
\end{aligned}
$$

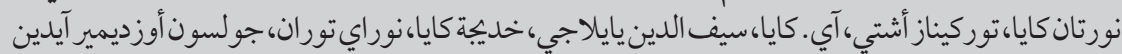

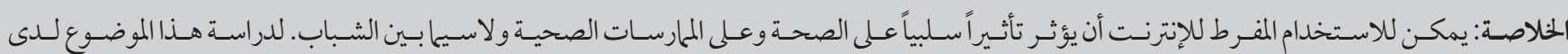

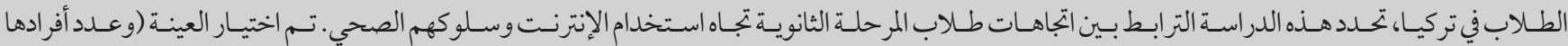

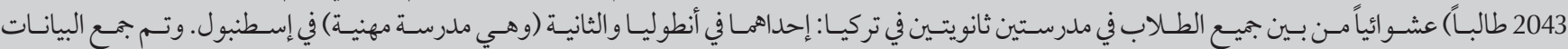

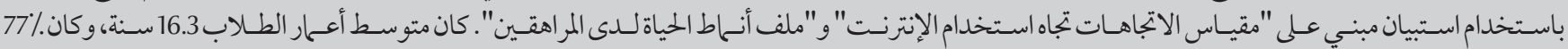

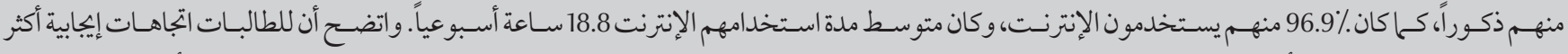



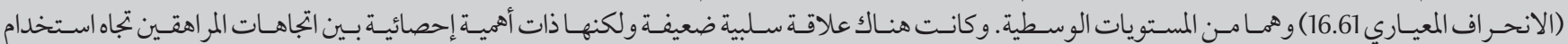

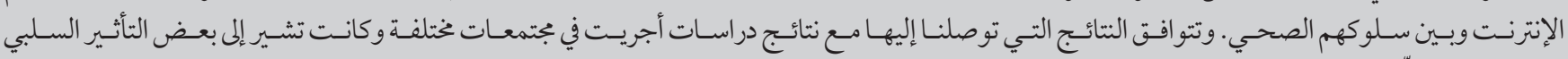

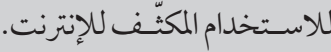

ABSTRACT Excessive usage of the Internet can negatively affect health and health practices especially among youth. To examine the issue among Turkish students, this study determined the association between high-school students' attitudes towards Internet usage and their health behaviour. The sample $(n=2043)$ was randomly drawn from all students at two high schools in Turkey: one in Anatolia and one (a vocational school) in Istanbul. Data were collected using the Structured Questionnaire, Attitude Scale towards Internet Usage (ASTIU) and Adolescent Lifestyle Profile (ALP). The mean age of the students was 16.3 years, $77.7 \%$ were male and $96.9 \%$ used the Internet; mean duration of Internet use was $18.8 \mathrm{~h} /$ week. Female students had more positive attitudes towards Internet usage. Mean scores for ASTIU and ALP were 72.58 (SD 17.64) and 111.34 (SD 16.61) respectively, which were average levels. There was a statistically significant but weak overall negative correlation between adolescents' attitudes towards Internet usage and their health behaviour. Our results concur with studies in different cultures which suggest some negative effects, of heavy Internet use.

Association entre les attitudes à l'égard de l'utilisation d'Internet et les pratiques sanitaires des élèves du secondaire dans deux établissements en Turquie : étude transversale

RÉSUMÉ Une utilisation excessive d'Internet peut nuire à la santé et aux pratiques sanitaires, notamment chez les jeunes. Afin d'étudier la question parmi les élèves turcs, la présente étude a déterminé l'association entre les attitudes des élèves du secondaire à l'égard d'Internet et leurs comportements en matière de santé. L'échantillon ( $n=2043)$ a été constitué de façon aléatoire à partir de l'ensemble des élèves de deux établissements d'enseignement secondaire en Turquie : I'un en Anatolie et l'autre dans une école de formation professionnelle à Istanbul. Les données ont été collectées à partir d'un questionnaire structuré, de I'ASTIU [échelle d'attitude à l'égard de l'utilisation d'Internet] et de l'ALP [profil de mode de vie des adolescents]. L'âge moyen des élèves était 16,3 ans, 77 \% étaient des garçons et 96,9\% utilisaient Internet, avec une durée moyenne totale d'utilisation de 18,8 heures par semaine. Les élèves de sexe féminin avaient des comportements plus positifs à l'égard de I'utilisation d'Internet. Les scores moyens pour l'ASTIU et I'ALP étaient de 72,58 (ET 17,64) et 111,34 (ET 16,61) respectivement, qui correspondaient aux scores moyens. Il existait une corrélation négative statistiquement significative, mais assez faible d'un point de vue global, entre les attitudes des adolescents à l'égard de l'utilisation $d^{\prime}$ Internet et leurs comportements en matière de santé. Nos résultats recoupent ceux d'études réalisées dans différentes cultures et qui suggèrent l'existence de certains effets négatifs liés à une utilisation excessive d'Internet.

'Health Sciences Faculty, Istanbul University, Istanbul, Turkey (Correspondence to: N. Kaya: nurka@istanbul.edu.tr, nurtenkaya66@gmail.com). 2Department of Nursing, Health Sciences Faculty, Bezmi Alem University, Istanbul, Turkey. ${ }^{3}$ Department of Metallurgy, inönü Technical and Industrial Vocational High School, Istanbul, Turkey. ${ }^{4}$ Nişantaşı Nuri Akın Anatolia High School, Istanbul, Turkey. ${ }^{5}$ Department of Fundamentals of Nursing Florence Nightingale Nursing Faculty, Istanbul University, Istanbul, Turkey

Received: 09/09/14; accepted: 03/08/16 


\section{Introduction}

Internet usage in all fields, such as education, health, communication, transportation, trade and finance, affects the world we live in $(1,2)$. The Internet has become pervasive in the lives of young people and there is evidence that it has a negative effect on academic attainment (drop in grades), family relations (having to hide excessive Internet usage from parents), physical health (sleep deprivation due to long hours of Internet usage), mental health (depression) and finance (cost of accrued Internet expenses) (3).

For high-school students, the Internet is one of the main sources of information and social interaction $(4,5)$. It enables them to access to information, do research and develop skills such as problem solving, creativity and critical thinking. On the other hand, excessive, uncontrolled and unthinking usage can have a negative effect on the development of personal skills and health and health practices $(6-8)$. For example, regular physical activity is essential for a healthy productive life. Modern life, with its cars, televisions, computers and video games, can lead to low levels of physical activity and necessitate deliberate commitment of leisure time to physical activity to gain health benefits $(9,10)$.

Health-risk behaviours are usually adopted in adolescence but their impact may not be felt until adulthood and may lead to a considerable increase in mortality and morbidity. Adolescents are therefore at a critical time in their life for making independent health care decisions; hence health promotion is especially important in this population (11). Health promotion aims to enable individuals to adjust their behaviours to attain a high level of physical and mental health.

As the Internet is an increasingly important resource of information in the lives of young people, it could be a valuable platform to deliver health interventions to youth populations; however, there is a lack of research in this field (12). This study among Turkish adolescents was therefore conducted to examine students' attitudes to the Internet and their health practices in view of the social norms in Turkey, such as strong family ties (13-15).

The specific aims of this study were to evaluate:

- the attitudes of students towards the Internet usage and their health practices;

- any correlation between Internet usage and students' health practices;

- the effect of sociodemographic and Internet-related characteristics on attitudes towards Internet usage and health practices.

\section{Methods}

\section{Study design and sample}

This was a cross-sectional study conducted in 2011/12. The study population consisted of all the students enrolled at one Anatolian high school and one vocational high school in Istanbul (total number of students $=3955$ ). Students were selected randomly from each school separately (by drawing names from separate bags for Anatolian and Istanbul students); thus 310 students were selected from the Anatolian high school and 1733 from the vocational high school in Istanbul (Table 1).

We conducted post hoc power analysis using $G^{*}$ Power 3.1.9.2 program. A significant difference was observed in the ASTIU scores $(z=3.66, P<0.001)$ between Internet users and non-users (Table 2). The statistical power analysis result for this difference was 0.97 .

\section{Data collection}

Data were collected by the researchers through face-to-face interviews with the students outside the classroom lessons using three data collection tools (Structured questionnaire, Attitude Scale towards Internet Usage and Adolescence Lifestyle Scale). The interviews were conducted in Turkish. To reduce social desirability bias, a randomized response technique was used $(16,17)$.

\section{Data collection tools}

Structured Questionnaire: It included questions regarding students' age, sex, body mass index (BMI) as measured by the researchers, and computer and Internet usage.

\section{Attitude Scale towards Internet}

Usage (ASTIU): It was designed by Tavşancil and Keser to assess attitudes towards Internet usage (18). It consists of 6 sub-dimensions: Usage of Internet in Instruction, Usage of Internet in Research, Usage of Internet in Social Interaction, Enjoyment of Usage of Internet in Instruction, Usage of Internet in Communication and Usage of Internet in Sharing of Knowledge. The 5-point Likert type scale consists of 31 items. The lowest and highest scores are 31 and 155 respectively. The higher the score in all sub-dimensions, the more positive the attitude towards Internet usage (amount and type of Internet use). The internal consistency coefficient for the whole scale was 0.89 (18). In the present study, the internal consistency coefficient was 0.88 , indicating ASTIU was a valid assessment tool for our study.

Adolescent Lifestyle Profile (ALP): The ALP is the version of Healthy Lifestyle Profile II developed for adolescents (9). Validity and reliability studies were conducted by Hendricks, Murdaugh and Pender (9), and a Turkish version was adapted by Ardıç (10). ALP consists of 40 items and 7 sub-dimensions: health responsibility, physical activity, nutrition, positive life appreciation, interpersonal relations, stress management, and spiritual growth. The lowest and highest scores obtainable are 40 and 160 respectively. The higher the score, the higher the level 


\begin{tabular}{lccc}
\hline Table 1 Distribution of population $(\mathbf{N}=\mathbf{3 9 5 5})$ & & \\
\hline Institution & Total no. of students $(\mathbf{S i})$ & Sample weight (ai) $^{\mathrm{a}}$ & No. of students in sample $^{\mathrm{b}}$ \\
Anatolian high school & 600 & 0.15 & 310 \\
Vocational high school & 3355 & 0.85 & 1733 \\
\hline
\end{tabular}

${ }^{a} a i=S i / N$.

${ }^{b} a i \times n$.

of health practice. The Cronbach alpha coefficient for the whole scale was 0.87 , range 0.54 to 0.77 for sub-dimensions (9). For the present study, it was 0.89 for the whole scale, range 0.53 to 0.72 for sub-dimensions. Internal consistency coefficients in our study were similar to Ardıç's (10), thus scale-related values had internal consistency.

\section{Statistical analysis}

SPSS 17 for Windows (version 11.0; SPSS Inc., Chicago, IL, USA) was used to analyse the data. Medians, minimum and maximum values and arithmetic means [standard deviation (SD)] were used for ordinal data evaluation. Frequency and percentages were used for nominal data evaluation. The Kolmogorov-Smirnov test was used to determine normality of distributions. As some distributions were abnormal, non-parametric methods were used for the statistical analysis. When comparing qualitative data, the Mann-Whitney U test was used to compare variables between two groups. The Kruskal-Wallis test was used to compare variables with more than two groups. The Bonferroniadjusted Mann-Whitney test was used to identify the responsible group for the difference with secondary multiple comparison analysis when the differences between the parameters of more than 2 groups were found statistically significant. Spearman correlation analysis was used to determine correlation between scales.

\section{Ethical considerations}

Prior to the study, authorized written approval was obtained from the Faculty of Medicine Ethics Committee, Istanbul University Cerrahpaşa
(03.02.2011/8087/C-07) and the Istanbul Provincial Directorate for $\mathrm{Na}$ tional Education (02.04.2011/19532). Student participants were informed about the aims and benefits of the study and their roles were explained; all agreed to participate. Their written approval was taken on the consent form. No names were entered on the data collection forms and they were kept separately from the consent form to protect the anonymity of the students.

\section{Results}

\section{Students' characteristics}

Of the 2043 students included in the study, 1587 (77.7\%) were male. The reason for the difference was due to the higher number of male students in the vocational high school. The age of the participants ranged from 14 to 19 years, mean age was 16.3 years; just over half $(55.2 \%)$ were aged $14-16$ years. In addition, $70.4 \%$ were at a normal weight in terms of BMI, $68.4 \%$ had personal computers and $96.9 \%$ used the Internet. The mean duration of Internet use was 18.8 hours perweek $(\mathrm{SD}=17.0)$ (Table 2).

\section{Association between sociodemographic \& Internet- related characteristics and ASTIU \& ALP scores}

Sex was significantly associated with ASTIU score; female students had more positive attitudes towards the Internet usage $(P<0.001)$ (Table 2). Age was not significantly associated with either ASTIU or ALP scores $(P>0.05)$ (Table 2).

BMI was significantly associated with ALP scores $(P<0.05)$. The difference between BMI groups resulted from the differences in scores obtained by normal-weight and overweight students $\left(X^{2}=8.28, P=0.041\right)$. In line with this finding, the students with normal weight had more positive lifestyle practices compared to overweight students (Table 2).

The students with personal computers had significantly lower ASTIU scores $(P<0.001)$ than those who did not own one. However, the opposite was true for ALP scores with computerowning students having higher ALP scores $(P<0.001)$. This finding shows that students owing a computer had more negative attitudes towards the Internet usage but reported more positive lifestyle practices than those not owning a personal computer (Table 2).

ASTIU scores of those using the Internet were also significantly lower than those who did not do so $(P<0.05)$, indicating that students using the Internet had more negative attitudes towards the Internet than non-users (Table 2).

ASTIU and ALP scores were associated with weekly duration of Internet usage; the longer the Internet usage of students, the more negative were their attitudes towards Internet usage and the more negative their health practices (Table 2).

\section{ASTIU \& ALP scores and correlations between them}

The mean (SD) ASTIU score was 72.58 (SD 17.64). For sub-dimensions, the mean (SD) scores were: 17.87 (SD 6.03) for Usage of Internet in Instruction, 16.16 (SD 4.65) for Usage of Internet in Research, $10.44(\mathrm{SD}=4.38)$ for Usage of Internet in Social Interaction, 10.54 (SD 3.26) for Enjoyment 




${ }^{a}$ Examined in the 1979 individuals who used the Internet.

$z=$ Mann-Whitney $U$ test $; \chi 2=$ Kruskal-Wallis test. Statistical significant set at $P<0.05$.

ASTIU = Attitude Scale towards Internet Usage; $A L P=$ Adolescent Lifestyle Profile; $S D=$ standard deviation.

of Usage of Internet in Instruction, 9.26 (SD 3.35) for Usage of Internet in Communication, and 8.32 (SD 3.57) for Usage of Internet in Sharing of Knowledge. For ALP, the mean (SD) score for the whole scale was 111.34 (SD 16.61). The mean (SD) scores for sub-dimensions were: 10.69 (SD 2.91) for health responsibility, 16.08 (SD 3.76) for physical activity, 15.97 (SD 3.23) for nutrition, 24.38 (SD 4.35) for positive life appreciation, 15.54 (SD 2.89) for interpersonal relations, 14.68 (SD 2.70) for stress management, and 13.99 (SD 2.92) for spiritual growth (Table 3).
While there was no correlation between students' attitudes towards the Internet usage and health responsibility, a very weak negative correlation was found between students' attitudes towards Internet usage and physical activity, nutrition, positive outlook on life, interpersonal relations, stress management, spiritual growth and general lifestyle practices (Table 4).

\section{Discussion}

Overall, we found a very weak negative association between attitudes towards the Internet usage and adolescents' health practices.
With regard to students' individual characteristics and Internet usage, we found that the majority of participants used both computers and the Internet, and more than half of them had their own personal computer. Similarly, a study conducted by Cömert and Kayıran among children and adolescents showed that $35.7 \%$ of the families had a computer in their homes and $21.7 \%$ had Internet access (19). Given the fact that the Internet facilitates access to information, the high access shown in our study is overall a positive finding because students can easily benefit from the opportunities afforded by the Internet. 


\begin{tabular}{|c|c|c|c|c|c|}
\hline Scale & $\begin{array}{l}\text { Potential } \\
\text { range }\end{array}$ & Minimum & Maximum & Median & Mean (SD) \\
\hline \multicolumn{6}{|l|}{ ASTIU } \\
\hline Usage of the Internet in instruction & $8-40$ & 8 & 40 & 17 & $17.87(6.03)$ \\
\hline Usage of the Internet in research & $7-35$ & 7 & 35 & 16 & $16.16(4.65)$ \\
\hline Usage of the Internet in social interaction & $4-20$ & 4 & 20 & 10 & $10.44(4.38)$ \\
\hline $\begin{array}{l}\text { Enjoyment from usage of the Internet in } \\
\text { instruction }\end{array}$ & $4-20$ & 4 & 20 & 10 & $10.54(3.26)$ \\
\hline Usage of the Internet in communication & $4-20$ & 4 & 20 & 9 & $9.26(3.35)$ \\
\hline Usage of the Internet in sharing of knowledge & $4-20$ & 4 & 20 & 8 & $8.32(3.57)$ \\
\hline Total & $31-155$ & 31 & 148 & 72 & $72.58(17.64)$ \\
\hline \multicolumn{6}{|l|}{$A L P$} \\
\hline Health responsibility & $5-20$ & 5 & 20 & 10 & $10.69(2.91)$ \\
\hline Physical activity & $6-24$ & 6 & 24 & 16 & $16.08(3.76)$ \\
\hline Nutrition & $6-24$ & 6 & 24 & 16 & $15.97(3.23)$ \\
\hline Positive life appreciation & $8-32$ & 8 & 32 & 25 & $24.38(4.35)$ \\
\hline Interpersonal relations & $5-20$ & 5 & 20 & 16 & $15.54(2.89)$ \\
\hline Stress management & $5-20$ & 5 & 20 & 15 & $14.68(2.70)$ \\
\hline Spiritual growth & $5-20$ & 5 & 20 & 14 & $13.99(2.92)$ \\
\hline Total & 40-160 & 40 & 160 & 111 & $111.34(16.61)$ \\
\hline
\end{tabular}

$S D=$ standard deviation .

In the current study, significant sex differences in Internet usage were observed; male students used the Internet more than females. Other studies have shown sex differences in amount and type of Internet use, but not consistently for one sex or the other (20-22). Macharia \& Nyakwende found that female university students in Kenya reported greater use of the Internet for study purposes than males (20). Similarly, a study conducted among high school students in Turkey reported that female students spent more time than male students on the Internet (6). However, a study in Australia observed that male adolescent students spent more time on the Internet than their female counterparts (21). Males in the United States of America were reported to use the Internet mainly for purposes related to entertainment and leisure whereas women used it primarily for interpersonal communication and educational assistance (22).
The correlation between the duration of the Internet use and ASTIU and ALP scores showed that longer Internet usage was associated with more negative attitudes towards its use and poorer health practices. Several studies confirm the negative effects of Internet use on health practices if it is used for extended periods of time. A study among students in Hong Kong reported that heavy Internet users were much less likely than others to engage in health-promoting behaviours such as attempting to eat a healthier diet, taking nutritional supplements and trying to increase physical activity levels (23). In a study among Turkish high-school students, Kelleci et al. showed that Internet usage in excess of 2 hours a day led to mental health disorders (6). Among a sample of adults (median age of 20 years), higher levels of computer usage were associated with both lower physical activity levels and perception of computer usage as a barrier to physical activity (24). Moreover, Morgan and Cotton, and Yang et al. suggested that excessive use of the Internet caused students to deviate from the real life and fail to cope with difficulties they encounter $(25,26)$. Participants of a study conducted by Rotunda et al. reported certain negative outcomes of Internet usage and that problematic practices, which were less prevalent, became more common (27).

The students' ASTIU scale total score was at a medium level (mean 72.58 in a range of $31-155$ ). Also Internet Usage in Instruction was the sub-dimension on which students got the highest scores. A study among adolescents in Lebanon indicated that $84.2 \%$ the Internet usage was for communication and messaging, $65.7 \%$ for information and research, $51.8 \%$ for entertainment such as gaming, $51.2 \%$ for music and movies, and $4.6 \%$ for other purposes (28). Thanks to its interactive nature, the Internet contributes to education and provides resources and materials in almost every field that can be used directly in the classroom. Furthermore, students in this information 


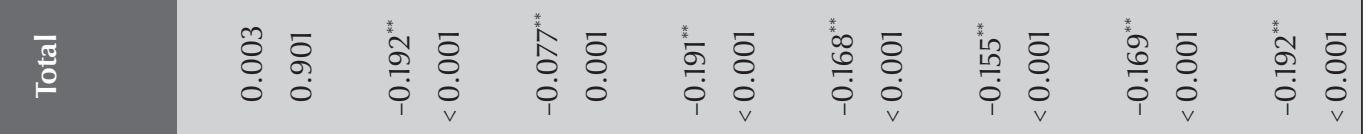



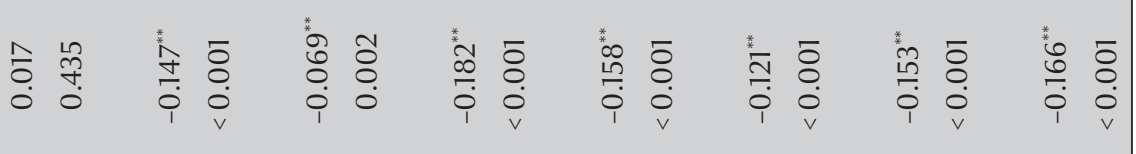

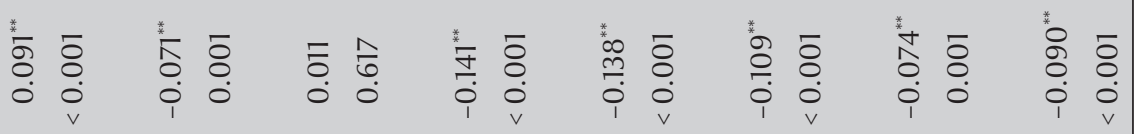

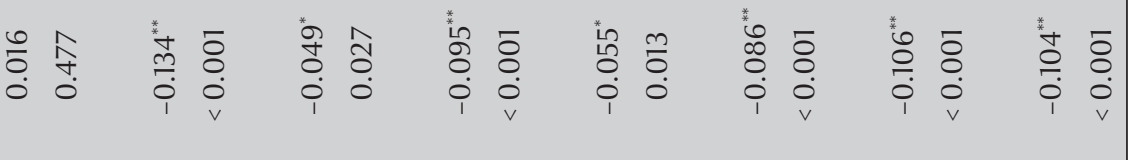

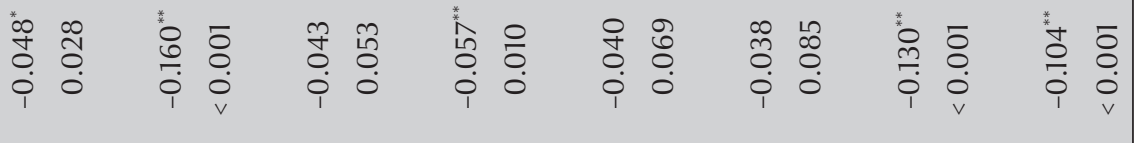

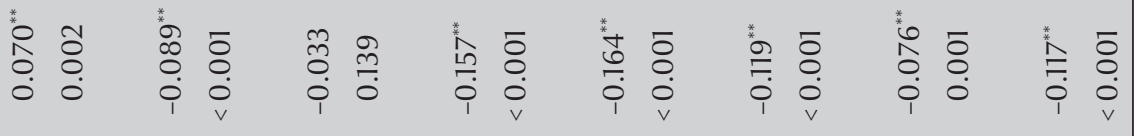

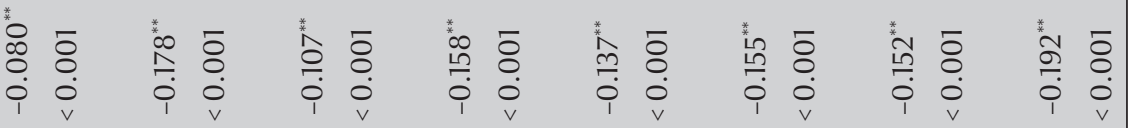

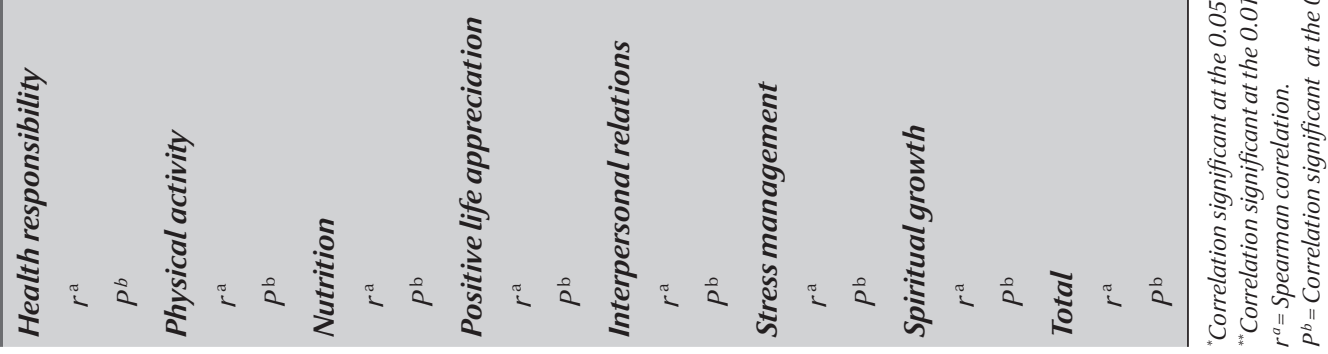


age are expected to self-learn through various resources, including the Internet, and be able to analyse and use information accessed. Using the Internet in a healthy and conscious fashion facilitates learning performance and enables adolescents to acquire and benefit from a variety of skills such as selecting collecting and categorizing information $(19,29)$.

The total score on the ALP scale was at a medium level (mean 111.34 in a range of 40-160). On the other hand "positive life appreciation" was the sub-dimension on which students got the highest scores. Scores for positive life appreciation indicate the level of adopting a positive view on life and having positive thoughts. It can be said that if young people have a positive outlook on life, it is a desirable outcome for their future in terms of adopting and maintaining positive health practices (10).

We observed that as students' ASTIU scores increased, physical activity, nutrition, positive outlook on life, stress management, spiritual growth and general lifestyle practices became more negative. A previous study in Turkey revealed that children and youngsters who spend a lot of time on the Internet become more and more isolated and experience difficulties in establishing face-to-face interactions (30). Other studies in the United States and Australia reported that excessive usage of the Internet could cause considerable problems in daily practices, interpersonal relations and business, and that some students could not establish close relationships with their friends due to the Internet usage $(31,32)$. Clark et al. confirmed that students who constantly use the Internet develop eyestrain, headache and pain in their neck and wrists in time and women exhibit more physical symptoms compared to men (33).

A main limitation to our study is that it was conducted in only 2 schools is Turkey and the sample may not be representative of schools across Turkey; hence the results may not be generalized to a wider population.

\section{Conclusion}

This current study was conducted to determine the effects of high school students' attitudes towards the Internet usage on their health practices. Weak negative correlations were found between students' attitude towards the Internet usage and physical activity, nutrition, positive outlook on life, interpersonal relations, stress management, spiritual growth, and general lifestyle practices. Thus it may be said that Internet use appears to have little effect on students' health practices. However, while showing weak effects, our results are similar to studies in different cultures which suggest some negative effect of heavy Internet use; some control of the heavy usage of the Internet may be warranted.

\section{Acknowledgements}

We would like to thank Istanbul University Scientific Research Projects Unit for funding the research.

Funding: Istanbul University Scientific Research Projects Unit (Project Number: 17720).

Competing interests: None declared.

\section{References}

1. Üneri ÖŞ, Tanıdır C. Evaluation of internet addiction in a group of high school students: a cross-sectional study. Journal of Psychiatry and Neurological Sciences. 2011;24:265-72.

2. Willoughby T. A short-term longitudinal study of Internet and computer game use by adolescent boys and girls: prevalence, frequency of use, and psychosocial predictors. Dev Psychol. 2008 Jan;44(1):195-204.

3. Guan SS, Subrahmanyam K. Youth Internet use: risks and opportunities. Curr Opin Psychiatry. 2009 Jul;22(4):351-6.

4. Okay Ş, Aydoğan E. MYO Öğrencilerinin internet kullanım amaçlarının incelenmesine ilişkin bir araştırma [A research on the vocational high school students' intentions of internet usage]. Selçuk Üniversitesi Sosyal Bilimler Enstitüsü Dergisi. 2010;23:283-96.

5. Webb TL, Joseph J, Yardley L, Michie S. Using the internet to promote health behavior change: a systematic review and meta-analysis of the impact of theoretical basis, use of behavior change techniques, and mode of delivery on efficacy. J Med Internet Res. 2010 02 17;12(1):e4.

6. Kelleci M, Güler N, Sezer H, Gölbaşı Z. Lise öğrencilerinde internet kullanma süresinin cinsiyet ve psikiyatrik belirtiler ile ilişkisi [Relationships gender and psychiatric symptoms with duration of internet use among high school students.]. Turk Silahli Kuvvetleri Koruyucu Hekim Bul. 2009;8(3):223-30.
7. Desai RA, Krishnan-Sarin S, Cavallo D, Potenza MN. Videogaming among high school students: health correlates, gender differences, and problematic gaming. Pediatrics. 2010 Dec;126(6):e1414-24.

8. Kim J, LaRose R, Peng W. Loneliness as the cause and the effect of problematic Internet use: the relationship between Internet use and psychological well-being. Cyberpsychol Behav. 2009 Aug;12(4):451-5.

9. Hendricks C, Murdaugh C, Pender N. The Adolescent Lifestyle Profile: development and psychometric characteristics. J Natl Black Nurses Assoc. 2006 Dec;17(2):1-5.

10. Ardıç A, Esin MN. The Adolescent Lifestyle Profile scale: reliability and validity of the Turkish version of the instrument. J Nurs Res. 2015 Mar;23(1):33-40.

11. Srof BJ, Velsor-Friedrich B. Health promotion in adolescents: a review of Pender's health promotion model. Nurs Sci Q. 2006 Oct;19(4):366-73.

12. Park BK, Calamaro C. A systematic review of social networking sites: innovative platforms for health research targeting adolescents and young adults. J Nurs Scholarsh. 2013 Sep;45(3):256-64.

13. Altan Ş, Atan M, Kızılkaya S. Genel sağlık durumunu etkileyen faktörlerin CHAID analizi yöntemi ile incelenmesi, ODTÜ örneği [An examination of factors affecting general health 
status via CHAID analysis, METU case]. NWSA: Social Sciences. 2015;10(3):92-106 (http://www.newwsa.com/download/ gecici_makale_dosyalari/-716-5528-2.pdf, accessed 21 September 2016).

14. Hallaç S, Öz F. Aile Kavramına Kuramsal Bir Bakış [A theoretical perspective of family concept]. Psikiyatr Guncel Yaklasimlar. 2014;6(2):142-53. 10.

15. Çalışkan N, Aslanderen M. Aile içi iletişim ve siber yaşam: Teorik bir çözümleme [Intra-family communication and cyber life: a theoretical analysis]. Ahi Evran Üniversitesi Kırşehir Eğitim Fakültesi Dergisi. 2014;15(2):263-77.

16. Nederhof AJ. Methods of coping with social desirability bias: A review. Eur J Soc Psychol. 1985;15:263-80.

17. Akgül A. Tıbbi Araştırmalarda Istatistiksel Analiz Teknikleri ve Analiz Yöntemleri [Statistical analysis techniques in medical research. SPSS Applications]. 2nd Edition. Ankara: Emek Printing Limited Company; 2003.

18. Tavşancıl E, Keser H. İnternet kullanımına yönelik likert tipi bir utum ölçeğinin geliştirilmesi [Development of a Likert type attitude scale towards Internet usage]. Eğitim Bilimleri ve Uygulama Dergisi. 2002;1(1):79-100.

19. Cömert IT, Kayıran SM. Çocuk ve ergenlerde internet kullanım [Internet use among children and adolescents]. Çocuk Dergisi. 2010;10(4):166-70

20. Macharia J, Nyakwende E. Gender differences in internet usage intentions for learning in higher education: An empirical study. Journal of Language Technology \& Entrepreneurship in Africa. 2011;3(1):244-54.

21. Wang W. Internet dependency and psychosocial maturity among college students. International journal of humancomputer studies. 2001;55:919-38.

22. Weiser EB. Gender differences in Internet use patterns and Internet application preferences: A two-sample comparison. Cyberpsychology \& Behavior. 2000;3(2):167-78.

23. Kim JH, Lau CH, Cheuk KK, Kan P, Hui HL, Griffiths SM. Brief report: Predictors of heavy Internet use and associations with health-promoting and health risk behaviors among Hong Kong university students. J Adolesc. 2010 Feb;33(1):215-20.

24. Fotheringham MJ, Wonnacott RL, Owen N. Computer use and physical inactivity in young adults: public health perils and potentials of new information technologies. Ann Behav Med. 2000 Fall;22(4):269-75.

25. Morgan C, Cotten SR. The relationship between internet activities and depressive symptoms in a sample of college freshmen. Cyberpsychol Behav. 2003 Apr;6(2):133-42.

26. Yang CK, Choe BM, Baity M, Lee JH, Cho JS. SCL-90-R and 16PF profiles of senior high school students with excessive internet use. Can J Psychiatry. 2005 Jun;50(7):407-14.

27. Rotunda RJ, Kass SJ, Sutton MA, Leon DT. Internet use and misuse. Preliminary findings from a new assessment instrument. Behav Modif. 2003 Sep;27(4):484-504.

28. Hawi NS. Internet addiction among adolescents in Lebanon. Comput Human Behav. 2012;28(3):1044-53 10.1016/j. chb.2012.01.007.

29. Özmutaf MN, Özgür Z, Gökmen F. Üniversite öğrencilerinin bilgisayar kullanımında birey sağlığı kapsamında genel bakış açıları [General point of view of the university students on computer usage in context of personal health]. Ege Tıp Dergisi [Ege Journal of Medicine]. 2008;47(2):81-6.

30. Ceyhan AA. Ergenlerin problemli internet kullanım düzeylerinin yordayıcıları [Predictors of adolescents' problematic Internet use levels]. Cocuk Ve Genclik Ruh Sagligi Dergisi. 2011;18(2):85-94.

31. Beard KW. Internet addiction: current status and implications for employees. J Employ Couns. 2002;39:2-11.

32. Wang W. Internet dependency and psychosocial maturity among college students. International Journal of HumanComputer Studies. 2001;55:919-38.

33. Clark DJ, Frith KH, Demi AS. The physical, behavioral, and psychosocial consequences of Internet use in college students. Comput Inform Nurs. 2004 May-Jun;22(3):153-61. 